\title{
GAMBARAN TINGKAT PENGETAHUAN KADER KESEHATAN TENTANG PERAWATAN KAKI DIABETES DI KOTA MAKASSAR 2019
}

\section{OVERVIEW OF KNOWLEDGE HEALTH VOLUNTEER ABOUT DIABETIC FOOT CARE IN MAKASSAR CITY 2019}

\author{
Elly L. Sjattar ${ }^{1}$, Sarnida ${ }^{2}$, Titi Iswanti Afelya ${ }^{3,}$ Abdul Majid ${ }^{4,}$ Kusrini Kadar $^{5,}$ Yuliana Syam ${ }^{6,}$ \\ Saldy Yusuf ${ }^{7}$ Nurhaya Nurdin ${ }^{8}$ \\ 1,3,4,6,7 Departemen Keperawatan Medikal Bedah Fakultas Keperawatan Universitas \\ Hasanuddin, Makassar \\ ${ }^{5,8}$ Departemen Keperawatan Komunitas Fakultas Keperawatan Universitas Hasanuddin, \\ Makassar \\ 2.Mahasiswa Program Studi Ilmu Keperawatan Fakultas Keperawatan Universitas Hasanuddin, \\ Makassar \\ Alamat Korespondensi: Jl. Perintis Kemerdekaan KM. 10 Kampus Unhas Tamalanrea, Program Studi Magister \\ Ilmu Keperawatan Fakultas Keperawatan, Makassar 90245 Email: ellyunhas@gmail.com
}

\begin{abstract}
ABSTRAK
Latar belakang: Diabetes mellitus (DM) adalah salah satu penyakit tidak menular yang dilaporkan meningkat setiap tahun. Seiring dengan meningkatnya jumlah penderita diabetes, komplikasi yang dapat terjadi juga meningkat. Salah satu komplikasi yang dapat terjadi adalah ulserasi pada tungkai bawah dengan atau tanpa infeksi yang menyebabkan kerusakan pada jaringan di bawahnya, yang selanjutnya disebut sebagai Diabetic Foot. Perawatan kaki yang tepat dapat meminimalkan faktor risiko dan hal-hal yang tidak diinginkan terjadi. Kunci keberhasilan dan bagian penting dari pengelolaan DM dengan Diabetes secara komprehensif adalah keterlibatan anggota tim seperti dokter, perawat, petugas kesehatan lainnya, orang dan keluarga mereka. Salah satu sukarelawan dari petugas kesehatan lain yang sering ditemukan di masyarakat, yaitu Kader Kesehatan. Salah satu tindakan yang dapat dilakukan oleh Kader Kesehatan adalah untuk mencegah timbulnya cedera pada kaki diabetes, mampu memberikan pendidikan kesehatan dan melakukan perawatan kaki yang baik dan benar untuk penderita diabetes. Tujuan Penelitian: Untuk mengetahui gambaran pengetahuan Kader Kesehatan tentang Perawatan Kaki Diabetes di Kota Makassar. Metode: Penelitian ini menggunakan metode penelitian deskriptif eksploratif. Jumlah sampel yang diperoleh adalah 79 responden dengan teknik purposive sampling pada Kader Kesehatan di kota Makassar. Instrumen yang digunakan adalah hasil penelitian dari kuesioner Konsensus Delphi (Abrar, Yusuf, \& Sjattar, 2019). Hasil penelitian menunjukkan bahwa 64 responden $(81 \%)$ memiliki pengetahuan tentang perawatan kaki Diabetes dalam kategori baik dan 15 responden memiliki pengetahuan tentang perawatan kaki diabetes dalam kategori kurang.
\end{abstract}

Kata kunci: Perawatan kaki diabetes, Kader kesehatan

\begin{abstract}
Background: Diabetes mellitus (DM) is one of the non-communicable diseases reported to have increased every year. Along with the increasing number of people with diabetes, the complications that can occur also increase. One of the complications that can occur is ulceration of the lower limb with or without infection which causes damage to the underlying tissue, hereinafter referred to as the Diabetic Foot. Proper foot care can minimize risk factors and unwanted things happen. The key to success and an important part of managing DM with Diabetes comprehensively is the involvement of team members such as doctors, nurses, other health workers, persons and their families. One of the volunteers from other health workers who is often found in the community, namely Health Volunteer. One of the actions that can be done by a Health Cadre is to prevent the onset of injuries to the foot of diabetes, which is able to provide education and perform good and correct foot care for people with diabetes. The Objective of the Research: To find out the description of Health Volunteer knowledge about Diabetes Foot
\end{abstract}


care in Makassar City. Method: This study uses descriptive explorative research methods. The number of samples obtained was 79 respondents with purposive sampling technique on Health volunteer. The instruments used were the research results of the Delphi Consensus questionnaire (Abrar, Yusuf, \& Sjattar, 2019). Results: The results showed that 64 respondents $(81 \%)$ had knowledge of Diabetes Foot care in a good category and 15 respondents had Diabetic Foot care in the less category.

Keywords: Diabetic Foot care, Health volunteer 


\section{PENDAHULUAN}

Diabetes melitus (DM) merupakan salah satu penyakit tidak menular yang di laporkan mengalami peningkatan setiap tahun. Estimasi terakhir yang dilaporan oleh International Diabetes Federation (IDF) yaitu terdapat 382 juta orang yang hidup dengan diabetes di dunia pada tahun 2013. Pada tahun 2014, terdapat 96 juta orang dewasa dengan diabetes di 11 negara anggota di wilayah regional Asia Tenggara. Sedangkan pada tahun 2015 terdapat 415 juta orang dewasa dengan diabetes, kenaikan 4 kali lipat dari 108 juta di 1980an (World Health Organization, 2016). Peningkatan prevalensi ini terjadi di seluruh dunia baik negara maju maupun negara berkembang seperti Indonesia. Pada tahun 2015, jumlah penyandang DM di Indonesia menduduki peringkat ke-7 dunia setelah China, India, Amerika Serikat, Brazil, Rusia, dan Meksiko dengan jumlah estimasi orang dengan diabetes sebesar 10 juta (International Diabetes Federation, 2015). DM dengan komplikasi juga menjadi penyebab kematian tertinggi ketiga di Indonesia (WHO, 2016). Selain ditingkat Internasional dan Nasional, peningkatan kejadian DM juga tercermin ditingkat Regional khususnya provinsi Sulawesi Selatan. Pada tahun 2013 prevalensi DM di Sulawesi Selatan yang terdiagnosis oleh dokter sebesar $1.6 \%$. Kota Makassar menempati urutan kedua dengan prevalensi kasus DM yang didiagnosis dokter sebesar 2,5\% setelah Kabupaten Pinrang. Selain itu, Kota Makassar juga menempati urutan kedua dengan prevalensi kasus Diabetes berdasarkan gejala tertinggi sebesar 5,3\% setelah Kabupaten Tana Toraja.

DM merupakan suatu penyakit kronis kompleks yang membutuhkan perawatan medis berkelanjutan dengan cara mengendalikan kadar gula darah untuk mengurangi risiko di luar kendali glikemik (International Diabetes Federation Atlas, 2017). Seiring meningkatnya jumlah penyandang DM, maka komplikasi yang dapat terjadi juga semakin meningkat.Salah satu komplikai yang dapat terjadi yaitu ulserasi pada tungkai bawah dengan atau tanpa infeksi yang menyebabkan kerusakan pada jaringan dibawahnya yang selanjutnya disebut dengan Kaki Diabetes. Kurangnya perawatan pada Kaki Diabetes dapat memunculkan risiko terjadinya ulkus Kaki Diabetes. Perawatan yang tepat dapat meminimalkan faktor risiko serta hal-hal yang tidak diinginkan terjadi. Oleh sebab itu, perawatan yang dilakukan sejak awal 
harus dikerjakan dengan benar, tepat dan teliti (Kartika R, 2017). Perawatan kaki merupakan upaya pencegahan primer serta deteksi dini yang dilakukan untuk mencegah terjadinya komplikasi yang lebih lanjut.

Kunci keberhasilan dan bagian penting dari penatalaksanaan DM dengan Kaki Diabetes secara komprehensif yaitu adanya keterlibatan antara anggota tim seperti dokter, perawat, petugas kesehatan yang lain, penyandang dan keluarganya (Smeltzer \& Bare, 2013. Salah satu tenaga relawan dari petugas kesehatan yang lain yang sering dijumpai dimasyarakat yaitu Kader Kesehatan. Kader Kesehatan dalam Permenkes No. 25 Tahun 2014 yang dikeluarkan oleh(Direktorat Jenderal Kesehatan Masyarakat, 2018) adalah orang yang dipilih oleh masyarakat kemudian dilatih dan dibekali materi dalam hal menangani masalah-masalah kesehatan baik itu perorangan atau masyarakat serta dapat bekerja di tempat-tempat yang ada kaitannya dengan pemberian pelayanan kesehatan. Kader Kesehatan menjadi tim penggerak, penghubung serta penyalur informasi masalah kesehatan pada puskesmas (Pusat Penanggulangan Krisis Kesehatan, 2015). Salah satu tindakan yang dapat dilakukan seorang Kader Kesehatan terkait pencegahan timbulnya luka pada kaki diabetes yaitu mampu memberikan edukasi dan melakukan perawatan kaki yang baik dan benar pada penyandang DM. Oleh karena itu bukan hanya dokter maupun perawat, Kader Kesehatan juga diharapkan mampu melakukan perawatan Kaki Diabetes dengan benar agar dapat menghindarkan penyandang DM dari berbagai komplikasi yang memicu terjadinya infeksi, kecacatan, amputasi atau bahkan kematian.

\section{BAHAN DAN METODE}

\section{Lokasi dan Rancangan penelitian}

Penelitian ini dilakukan di Wilayah kerja Puskesmas Bulurokeng, Puskesmas Ballapparang, Puskesmas Mamajang dan Puskesmas Jumpandang Baru. Jenis penelitian ini menggunakan survey Deskriptif eksploratif.

\section{Populasi dan sampel}

Populasi adalah Kader kesehatan di Kota Makassar. Besar sampel dalam penelitian ini yaitu sebanyak 79 responden yang diperoleh melalui rumus slowvin, yang dipilih secara purposive sampling yang telah memenuhi kriteria inklusi yaitu Kader yang terdaftar pada Puskesmas Bulurokeng, Ballaparang, Mamajang 
dan Jumpandang Baru, Kader

Kesehatan yang dalam 6 bulan sampai 1 tahun terakhir aktif ikut serta dalam program yang telah dilaksanakan oleh Puskesmas dan bersedia menjadi responden.

\section{Metode pengumpulan data}

Pengumpulan data menggunakan kuisioner data demografi dan instrumen hasil konsensus delphi dari hasil penelitian (Abrar, Yusuf \& Sjattar, 2019).

\section{Analisis data}

Analisis data dilakukan menggunakan uji descriptive.

\section{HASIL}

\section{Karakteristik responden}

Tabel 1. Memperlihatkan karateristik kader kesehatan yang menjadi responden penelitian ini. Kader kesehatan berusia pada rentang $25-83$ tahun, dan sebagian besar kader kesehatan berusia rata-rata 45 tahun. Pendidikan Kader Kesehatan yang paling banyak adalah SMA (63.3\%) dan paling rendah adalah SD (3.8\%). Pekerjaan terbanyak adalah ibu Rumah tangga (87.3\%), dan paling sedikit adalah Pegawai Negeri Sipil (2.5\%). Hampir seluruh Kader belum pernah mendapatkan penyuluhan tentang perawatan kaki diabeter $(92.4 \%)$. Kader kesehatan yang berpartisipasi dalam penelitian ini berasal dari ke-4 Puskesmas di Kota Makassar, diantaranya Puskesmas Bulurokeng 17 responden (21.5\%), Puskesmas Ballaparang 21 responden (26.6\%), Puskesmas Mamajang 21 responden (26.6\%) dan Puskesmas Jumpandang Baru 20 responden (25.3\%).

\section{Pengetahuan Perawatan kaki diabetes}

Tabel 2. menunjukkan bahwa sebagian besar responden sebanyak 64 responden (81\%) memiliki pengetahuan yang baik tentang perawatan Kaki Diabetes pada penyandang DM, dan 15 responden (19\%) yang pengetahuan kurang.

Pada Tabel 3 mendeskripsikan pengetahuan Kader kesehatan berdasarkan tiap komponen/sub variabel dari perawatan kaki. Responden memiliki pengetahuan yang baik pada pemeriksaan kaki (86.1\%), Mencuci kaki (68.4\%), Mengeringkan kaki (53.2\%), Penggunaan pelembab (49.4\%), Memotong kuku (70.9\%), Penggunaan kaos kaki (67.1\%) dan Penggunaan alas kaki $(84.8 \%)$. 
Tabel 1. Distribusi karakteristik Kader Kesehatan di Kota Makassar

\begin{tabular}{|c|c|c|c|c|c|c|c|}
\hline & \multirow{2}{*}{ Variabel } & \multicolumn{2}{|c|}{ Frekuensi } & \multirow{2}{*}{ Mean } & \multirow[b]{2}{*}{ Median } & \multirow{2}{*}{ SD } & \multirow{2}{*}{$\begin{array}{l}\text { Min- } \\
\text { Maks }\end{array}$} \\
\hline & & $\mathrm{n}$ & $\%$ & & & & \\
\hline Umur & & & & 44.57 & 43.00 & 10.065 & $25-83$ \\
\hline \multicolumn{8}{|c|}{ Pendidikan } \\
\hline & SD & 3 & 3.8 & & & & \\
\hline & SMP & 19 & 24.1 & & & & \\
\hline & SMA & 50 & 63.3 & & & & \\
\hline & Perguruan Tinggi & 7 & 8.9 & & & & \\
\hline \multicolumn{8}{|c|}{ Pekerjaan } \\
\hline & Tidak & & & & & & \\
\hline & Bekerja/IRT & 69 & 87.3 & & & & \\
\hline & PNS & 2 & 2.5 & & & & \\
\hline & Wiraswasta & 4 & 5.1 & & & & \\
\hline & Swasta & 4 & 5.1 & & & & \\
\hline \multicolumn{8}{|c|}{ Penyuluhan } \\
\hline & Dapat & & & & & & \\
\hline & Penyuluhan & 6 & 7.6 & & & & \\
\hline & Tidak dapat & 73 & 92.4 & & & & \\
\hline \multicolumn{8}{|c|}{ Puskesmas } \\
\hline & Bulurokeng & 17 & 21.5 & & & & \\
\hline & Ballaparang & 21 & 26.6 & & & & \\
\hline & Mamajang & 21 & 26.6 & & & & \\
\hline & Jumpandang Baru & 20 & 25.3 & & & & \\
\hline
\end{tabular}

Tabel 2. Gambaran pengetahuan Kader Kesehatan di Kota Makassar

\begin{tabular}{ccc}
\hline Pengetahuan Perawatan Kaki & $\mathrm{n}$ & $\%$ \\
\hline Baik & 64 & 81 \\
Kurang & 15 & 19 \\
\hline
\end{tabular}

Tabel 3 Distribusi skor pengetahuan Kader Kesehatan berdasarkan Komponen/Sub Variabel dari perawatan Kaki di Kota Makassar

\begin{tabular}{lcccc}
\hline \multicolumn{1}{c}{ Sub Variabel } & \multicolumn{2}{c}{ Baik } & \multicolumn{2}{c}{ Kurang } \\
\cline { 2 - 5 } & $\mathrm{n}$ & $\%$ & $\mathrm{n}$ & $\%$ \\
\hline Pemeriksaan kaki & 68 & 86.1 & 11 & 13.9 \\
\hline Mencuci kaki & 54 & 68.4 & 25 & 31.6 \\
\hline Mengeringkan kaki & 42 & 53.2 & 37 & 46.8 \\
\hline Penggunaan pelembab & 39 & 49.4 & 40 & 50.6 \\
\hline Memotong kuku & 56 & 70.9 & 23 & 29.1 \\
\hline Penggunaan kaos kaki & 53 & 67.1 & 26 & 32.1 \\
\hline Penggunaan alas kaki & 67 & 84.8 & 12 & 15.2 \\
\hline
\end{tabular}




\section{PEMBAHASAN}

Gambaran pengetahuan Kader Kesehatan tentang perawatan Kaki Diabetes di Puskesmas Bulurokeng, Ballaparang, Mamajang dan Jumpandang Baru Kota Makassar

Hasil penelitian mengenai pengetahuan Kader Kesehatan tentang perawatan Kaki Diabetes didapatkan bahwa sebagian besar responden yakni sebanyak 64 (81\%) responden memiliki pengetahuan dalam kategori baik. Dan sebanyak 15 responden (19\%) memiliki pengetahuan dalam kategori kurang. Selain itu, penelitian ini mendapatkan hasil bahwa Kader Kesehatan mampu menjawab pertanyaan dengan baik pada setiap item pertanyaan. Hal ini dibuktikan dari 7 kategori Sub Variabel yang disiapkan, hanya 1 item dimana Kader Kesehatan lebih banyak menjawab pertanyaan dengan kurang dibandingkan yang menjawab dengan baik pertanyaan tersebut. Selebihnya, persentase Kader Kesehatan menjawab dengan baik pertanyaan yang lain lebih tinggi dibandingkan yang menjawab pertanyaan dengan kurang tepat.

Dari 10 item pertanyaan yang kemudian dikategorikan dalam 7 Sub Variabel, ditemukan bahwa Kader
Kesehatan mengetahui bagaimana pemeriksaan kaki pada penyandang DM, cara mencuci kaki, mengeringkan kaki, memotong kuku, penggunaan kaos kaki serta alas yang tepat. Hal ini dibuktikan dengan persentase Kader Kesehatan yang menjawab dengan baik pertanyaan lebih besar dibandingkan yang menjawab kurang tepat pertanyaan tersebut. Namun pertanyaan dengan jawaban yang kurang tepat paling banyak ditemukan pada penggunaan krim pelembab, dibuktikan dengan banyak Kader Kesehatan yang kurang mengerti pada saat kapan dan pada bagian kaki yang mana pelembab dapat digunakan. Akan tetapi, meski tidak pernah mendapatkan penyuluhan tentang perawatan Kaki Diabetes secara spesifik, namun ternyata pengetahuan Kader Kesehatan terkait perawatan Kaki Diabetes dikategorikan memiliki pengetahuan dalam kategori yang baik.

Pada saat dilakukan penelitian, banyak Kader Kesehatan yang mengaku sudah pernah atau bahkan sering membantu merawat keluarganya yang merupakan penyandang DM. Dengan dibekali oleh pengalaman, Kader Kesehatan dengan mudah dapat menjawab pertanyaan meski tidak semua jawabannya benar. Seperti yang 
dijelaskan oleh (Badariah, Wiarsih, \& Permatasari, 2014), Mampu merawat anggota keluarga yang merupakan penyandang DM ternyata dapat meningkatkan status kesehatan penyandang DM tersebut. Pengalaman dalam merawat anggota keluarga sebagaimana yang dimaksudkan adalah kemampuan anggota keluarga dalam melaksanakan dan memperhatikan kesehatan keluarga yaitu melalui kemampuan mengenali masalah kesehatan yang dialami, mengambil keputusan yang tepat dalam bertindak, mampu merawat dan memodifikasi lingkungan serta memanfaatkan pelayanan kesehatan.

Selain karena pengalaman, Kader Kesehatan juga mengaku sebelumnya pernah membaca atau mengakses informasi melalui internet sehingga penyaluran informasi menjadi lebih mudah didapatkan. Ini dibuktikan dari pengakuan Kader Kesehatan yang mengaku ketika penasaran akan beberapa informasi maka dengan mudah mengakses informasi diinternet dan menyebarkan informasi kepada sesama. Didukung oleh penelitian (Supriyanto \& Hartono, 2017) yang mengungkapkan bahwa sosialisasi mengenai penggunaan serta pemanfaatan internet bagi Kader
Kesehatan menjadi salah satu hal yang sangat penting dan sangat perlu. Tujuannya agar pemanfaatan akses internet dapat diterapkan dengan baik. Hal ini dimaksudkan untuk lebih mempermudah dan mempercepat proses pelaporan informasi serta penyajian informasi sesuai dengan kebutuhan. Selain itu, menurut (Budiman, 2017), perkembangan teknologi infomasi yang semakin pesat di era globalisasi seperti sekarang ini sangat besar pengaruhnya terhadap dunia pendidikan dalam rangka peningkatan mutu pendidikan.

Hal lain yang ditemukan selama penelitian, meskipun mayoritas Kader Kesehatan tidak pernah mendapatkan penyuluhan tentang perawatan kaki namun ternyata kategori pengetahuannya dalam kategori baik. Salah satu faktor yang menyebabkan hal ini terjadi adalah lebih dari setengah jumlah Kader Kesehatan secara keseluruhan memiliki latar belakang pendidikan SMA. Ini di dukung oleh penelitian (Siagian, Ottar, \& Palandeng, 2015), yang menjelaskan bahwa salah satu tercapainya pengetahuan yang baik yaitu karena pendidikan Kader Kesehatan yang cukup tinggi yaitu berasal dari tingkat SMA dimana pendidikan dasar tentang DM telah diajarkan disekolah sebelumnya. 
Namun terlepas dari semua itu, pelatihan dan pemberian edukasi oleh tenaga kesehatan juga sangat penting dan diperlukan agar informasi dapat secara merata di sebarluaskan kepada Kader Kesehatan yang mungkin sama sekali tidak pernah mendaptkan materi tersebut. Ini dibuktikan oleh penelitian (Siagian, Ottar, \& Palandeng, 2015) yang mengungkapkan bahwa sangat penting menjalankan program penyuluhan baik itu pada Kader Kesehatan maupun penyandang DM agar mereka dapat mengetahui penanganan yang tepat dan benar dalam melakukan perawatan entah untuk dirinya ataupun terhadap orang lain. Penyuluhan juga merupakan hal penting dalam rangka membendung angka kejadian ataupun kasus baru dari DM. Selain itu, program pelatihan atau penyuluhan DM secara efektif terhadap Kader Kesehatan bertujuan agar terselenggaranya pengendalian faktor risiko untuk menurunkan angka kesakitan, kecacatan, dan kematian sehingga Kader Kesehatan diharapkan dapat meningkatkan kesadaran dan komitmen untuk mengikuti pelatihan jika akan diadakan.

Penelitian yang dilakukan oleh (Mubarrok \& Nurkhoiri, 2017) juga menjelaskan bahwa salah satu hal yang tidak kalah penting adalah, pemberian edukasi yang bertujuan untuk memberikan pemahaman mengenai proses perjalanan penyakit, pencegahan yang dapat dilakukan, penghambat dalam proses pengobatan serta penatalaksanaan yang dapat dilakukan terkait penyakit DM.

\section{KESIMPULAN DAN SARAN}

Kami menyimpulkan, dari 79 Kader Kesehatan yang menjadi responden menjelaskan tidak pernah mendapatkan penyuluhan tentang perawatan Kaki Diabetes. Tetapi, hasil dari penelitian ini membuktikan bahwa pengetahuan Kader Kesehatan tentang perawatan Kaki Diabetes masuk dalam kategori memiliki pengetahuan yang baik. Hal ini di karenakan mudahnya mendapatkan informasi melalui internet, pengalaman Kader Kesehatan dalam merawat anggota keluarga yang menjadi penyandang DM serta memiliki latar belakang pendidikan yang cukup tinggi yaitu SMA. Meski begitu, penyuluhan serta pelatihan tetap dianggap sangat penting karena informasi yang didapatkan masih sedikit dan belum tersebar secara menyeluruh ke semua anggota Kader Kesehtan karena jika dilakukan penyuluhan hanya berapa orang yang menjadi perwakilan untuk ikut serta. 


\section{DAFTAR PUSTAKA}

Abrar, E. A., Yusuf, S., \& Sjattar, E. L. (2019). Pengembangan Instrumen Perawatan Kaki untuk Pasien Diabetes dalam Upaya Pencegahan Terjadinya Luka Kaki Diabetes (LKD): Study Delphy. Vol. 5, Nomor 1, Halaman 3237. Jurnal Kesehatan Manarang. DOI: https://doi.org/10.33490/jkm.v5i1.81

Budiman, H. (2017, Mei). Peran Teknologi Informasi Dan Komunikasi Dalam Pendidikan, Volume 8. (Universitas Islma Negeri Raden Intan Lampung) Retrieved Januari 20, 2019, from AlTadzkiyyah : Jurnal Pendidikan Islam:

http://ejournal.radenintan.ac.id/index. php/tadzkiyyah/article/download/209 $5 / 1584$

Direktorat Jenderal Kesehatan Masyarakat. (2018). Buku KIE Kader Kesehatan Remaja. (L. S. Rohaeti, S. Christanti, F. Marthatilova, \& H. S. Zulaidah, Eds.) Jakarta: Kementerian Kesehatan RI.

International Diabetes Federation. (2015). IDF Diabetes Atlas Seventh Edition. International Diabetes Federation.

International Diabetes Federation Atlas. (2017). IDF Diabetes Atlas Eighth Edition. International Diabetes Federation.

Kartika, R. W. (2017). Pengelolaan Gangren Kaki Diabetik. Fakmultas Kedokteran. Jakarta: Universitas Kristen Krida Wacana.

Mubarrok, A. S., \& Nurkhoiri, A. (2017). Upaya Pemberdayaan Kader Kesehatan Dalam Peningkatan Self Efficacy Pada Penderita Diabetes Mellitus. (Stikes Pemkab Jombang)
Retrieved Januari 20, 2019, from Prosiding Seminar Nasional Hasil Penelitian Dan Pengabdian Masyarakat Seri Ke-1: http://ejurnalp2m.stikesmajapahitmoj okerto.ac.id/index.php/publikasi_stike s_majapahit/article/download/234/20.

Pusat Penanggulangan Krisis Kesehatan. (2015). Buku Pegangan Kader Pemberdayaan Masyarakat Mengelola Menghadapi Krisis Kesehatan. Jakarta: Kementerian Kesehatan RI.

Siagian, I., Ottar, R. I., \& Palandeng, H. (2015, Februari 1). Gambaran Perilaku Kader Kesehatan Terhadap Diabetes Melitus Tipe 2 Di Puskesmas Kota Manado, Volume 3 Nomor 1. (Universitas Sam Ratulangi) Retrieved Januari 20, 2019, from Jurnal Kedokteran dan Komunikasi Tropik: https://ejournal.unsrat.ac.id/index.php /JKKT/article/view/6584

Smeltzer, S. C., \& Bare, B. G. (2013). Keperawatan Medikal Bedah (8 ed., Vol. 2). (E. Pakaryaningsih, M. Ester, Eds., H. Y. Kuncara, E. Ester, A. Hartono, \& Y. Asih, Trans.) Jakarta: EGC.

Supriyanto, A., \& Hartono, B. (2017, Oktober 28). Peran Teknologi Informasi Bagi Kader Posyandu Dalam Kegiatan Pendataan K.I.A. (UNISBANK Semarang) Retrieved Januari 20, 2019, from Seminar Nasional Vokasi dan Teknologi (SEMNASVOKTEK):

http://eproceeding.undiksha.ac.id/ind ex.php/semnasvoktek/article/downlo $\mathrm{ad} / 706 / 482 /$.

World Health Organization. (2016). Diabetes Fact And Number. World Health Organization. 